\title{
Microglia: roles and rules in brain traumatic injury
}

\author{
Hernando Raphael Alvis-Miranda, Gabriel Alcala-Cerra ${ }^{1}$, \\ Luis Rafael Moscote-Salazar ${ }^{1}$
}

University of Cartagena, Colombia

${ }^{1}$ Neurosurgery

\begin{abstract}
Microglia are a special type of supporting cells in the nervous system. between the functions they perform are myelin production, structural support, regulation of extracellular fluid, glial scar formation among others. This cell type for its versatility, is also related to pathological events, where his multiple roles and the release of proinflammatory factors can contribute to understand especially in traumatic brain injury, as secondary injury and the healing process, important aspects the context of brain injury.
\end{abstract}

Key words: microglia, Brain trauma Injury, neurons, neurotrauma

\section{Introduction}

The role of microglia in the neurotrauma has been under continuous debate, researches have been trying to state how microglia-mediated inflammation can contribute to recovery of function after trauma, or fell in secondary injury. Microglia, are resident cells of the brain involved in regulatory processes critical for development, maintenance of the neural environment, injury, and repair (1). Microglia derives from mesodermal precursor cells of hemapoietic lineage that populate the central nervous system (CNS) in early development. Resident microglia cells are turned over slowly, and are replenished throughout adult life by proliferation (2), and represent the resident macrophages of the CNS, accounting for $10 \%$ of the adult glial cell population in the normal brain (3). Morphologically distinct from neurons and astrocytes, these cells were classified by Cajal in 1913 as a third element of CNS (4). Del Río Hortega made a further distinction between microglia and other glial cells in 1932. At that time the morphological classification of microglia allowed three kinds of states: ramified, intermediate forms, and ameboid (5). Recent studies have evolved the classification to include a functional connotation like M1 and M2 phenotypes (6). These phenotypes, allows them to actively participate in pathological processes by changing their morphology, expressing various antigens and becoming phagocytic (7).

Microglia cells function as sentinels for innate immunity in the CNS continually monitoring and screening the extracellular environment, walling off areas of the CNS from foreign tissue, and removing damaged or dead cells (1), to achieve that, these cells express various sets of pattern recognition receptors (PRRs) in response to pathogenassociated molecular patterns (PAMPs) that include Toll-like receptors (TLRs; e. g: TLR-4) and inflammasomes (8). Very often, microglia cells provide the first line 
defense against invading germs, and interacting with neurons and other glial cells, they can be the first sense of critical changes in the neuronal activity.

Although microglial cells are thought to contribute to most pathological conditions, including CNS infections, neuroinflammatory lesions, brain tumors, and neurodegenerative diseases, their exact role in CNS development, homeostasis, and disease remains poorly understood (3). Regarding to neurotrauma, exists a strongly investigated feature, and that is the histological evidence of a prominent microglial activation (9). Currently there are many medical conditions under research because of the microglia activation in their pathological processes $(10,11,12$, 13).

This review will explore the current concepts and researches on microglial responses to CNS traumatic injury and also will be discussed the differential role of microglia.

\section{General response of microglia to injury}

For microglial activation no large amount of tissue damage is required; alterations of neural electric transmission or extracellular electrolyte composition and the release of soluble factors normally confined to the intracellular compartment are sufficient to trigger microglia cells activation.

In the healthy mature CNS, microglia have a ramified morphology, a small soma with fine cellular processes, this appearance has been associated with microglial "resting state". When CNS is insulted, either for trauma, infection, ischemia, neurodegenerative disease $o$ an altered neuronal activity, microglia can evoke rapid and intense changes in their cell shape, gene expression and functional behavior, all these changes conjure the "microglial activation" (14), as will be discussed later more precisely, microglia cells respond by detecting lipopolysaccharide (LPS) (8), beta-amyloid $(\mathrm{A} \beta)(15)$, thrombin, IFN- $\gamma$, and other proinflammatory cytokines (16).

In this late state, microglia suffer a morphological transformation, induction of a wide range of soluble factors, like cytokines, free radicals and nitric oxide, acquire a phagocytic phenotype (17) to clear tissue debris, damaged cells, or germs, and get physically associated with injured neurons. Microglial activation may result in expression of MHC (18) antigens and costimulatory molecules and in the capacity of microglia to act as antigen presenting cells. Microglial activation has key features: first, these cells react to all CNS pathologies, no matter if they are acute or chronic. Second, the response evoked is graded, and can range from very slight morphological changes accompanied by minor immunological activation, to the development of full-blown tissue macrophages with the associated expression of an entire battery of membrane bound and soluble immunologically relevant molecules (19). Because of the "immune privilege" (20) of the CNS, i. e., that the brain parenchyma has to protect itself from the potentially detrimental consequences of an immune reaction, the microglial activation is a highly regulated process. It is important to recognize the fact that microglia in "resting state", actively scan and monitor the extracellular environment by pinocytosis (21), always ready to transform to a state of "activity", in which microglia primarily serve for support and protection. So, the transition from a "resting" mode to an executive state thereby 
represents a shift in activities rather than "activation" phenomenon, then, there are no periods of inactivity.

Once microglial cell "activation" occurs, it starts with an emergency like response, such as defense oriented functions, i. e., combat an infection or to limit additional damage after injury. Eventually, the activated population, convert to a repairoriented response, for tissue reparation.

Although much effort has been directed toward characterizing the fundamental properties of an activated microglial cell, surprisingly little is known about the intrinsic molecular mechanisms that program the functional state of these cells in either the healthy or the diseased CNS (22), but these molecular mechanisms can be grouped to produce five stages: proliferation, migration, secretion of soluble products and electrophysiological changes.

\section{- Proliferation:}

Irrespective of the type of CNS lesion, microglial cells show an early proliferative response, usually proliferation indices, i. e., the number of actively proliferating microglial cells divided by the total number of microglial cells, peak around 3-5 days after a lesion (19). This proliferative response rapidly declines subsequently and approaches control levels 7-15 days after injury; but even after the zenith of the proliferation index, the total number of microglial cells can remain elevated, and depending on the type of injury, will still being significantly higher than pre-lesion values around a month after an experimental injury $(23,24,25)$.

The proliferation of microglial cells is triggered by damage to adjacent neurons, and deafferentation of central neurons by peripheral axotomy is a sufficient stimulus to induce it. A number of different factors have been shown to play important roles in the initiation of microglial proliferation but even actually is an incompletely answered world. In laboratory experiments have been demonstrated the presence of macrophagecolony stimulating factor (M-CSF) as a driver of the cell cycle of microglia, inducing their proliferation (26). Purinergic receptor $\mathrm{P} 2 \mathrm{X} 7$ also controls microglial proliferation (27). Others microglial mitogens are the granulocyte/monocyte colony-stimulating factor (GM-CSF), brain-derived neurotrophic factor (BDNF), neurotrophin (NT)-3, IL-1, IL-5, and chemokines (e. g., fractalkine and its receptor CXC3CL1) $(28,29,30,31,32,33)$. In the other hand, the proliferation regulation or inhibition seems to be exerted by the Transforming growth factor beta (TGF- $\beta$ ), mainly produced by activated astrocytes (34). In microglial cells proliferation, also are important the cell-cell interactions, particularly with neurons (35), which have key roles in delivery of regulatory signals, in part through the glycoprotein OX-2 (36). Microglia are equippated with glutamate-, purinergic-, acetylcholine-, adrenergic-, dopamine-, neurokinin-, serotoninergic-, opioid- and gamma-amino-butyric-acid-receptors, implicating that for their function is important the neuronal activity detection, but, microglia neurotransmitter receptor aren't in a specialized region in close apposition to neurotransmitter release sites. Spatial proximity to synapses can be attained transiently; the long-term association is not likely since microglia cells are highly motile in resting and activated states (21). Neuron-microglia communication relies mostly on release of signaling molecules from extrasynaptic 
axonal varicosities, as well as their diffusion from synapses.

\section{- Migration}

Microglia processes are capable of rapid extension $(\approx 1.25 \mathrm{~mm} / \mathrm{min})$ towards sites of acute CNS damage (37). The main candidate for a chemoattractant sensed by microglia is adenosine triphosphate [ATP; involves $\mathrm{G}(\mathrm{i} / \mathrm{o})$ proteins and the mitogenactivated protein kinase (MAPK)/extracellular signal-regulated kinase (ERK)-dependent pathway] (38) through microglial P2Y12 receptors (39) and an outward potassium current (40). Neuropeptides such as angiotensin II, bradykinin (controlled by a G(i/o)-proteinindependent pathway), endothelin, galanin [induces microglial migration in a similar way to bradykinin, but induces intracellular $\mathrm{Ca}(2+)$ mobilization by inositol-3, 4, 5trisphosphate $(\operatorname{InsP}(3))$-dependent $\mathrm{Ca}(2+)$ release from the intracellular store] and neurotensin are also chemoattractants for microglia. The fact that there are different intracellular signaling cascades indicates that chemoattractants control distinct microglial functions. Nitric oxide (NO) also is an additional guidance cue involved in microglia migration.

\section{- Secretion of soluble factors}

These are derived mainly from the activated microglia, and consist of cytokines, proteases, free radicals and growth factors. Proinflammatory cytokines, which are closely involved in various diseases (including trauma, ischemia, Alzheimer's disease, epilepsy, and others), play important roles in the facilitation of activated microglia for astrocytic activation (34). Among the most important cytokines is IL-1 (41), showing neurotoxic actions, and stimulating astrocytes and other microglial cells in paracrine and autocrine way. Its receptor is also founded both in neurons and glial cells. IL-1 induces expression of other proinflammatory mediators like IL-6 (42), and TNF- $\alpha$ (43), thus this interleukin seems to play a regulating role in the concert of cytokines, and binding results in activation of a series of intracellular adaptor molecules, mitogen activated protein (MAP) kinases and the transcription factor, nuclear factor kappa $\mathrm{B}$ (NF-kB), leading to changes in gene expression. The first cells to express IL-1 are microglia, but other brain cells (astrocytes, invading immune cells, vascular cells and probably neurons) can also produce IL-1 (41). Once the microenvironment of the CNS becomes activated, local cells also produce proinflammatory cytokines, chemokines and upregulate inmunomodulatory surface markers. These changes in turn decrease the stringency of the blood-brain barrier, allowing entry of other soluble factors and peripheral immune cells, including macrophages, natural killer cells and lymphocytes. Proteases are also very important after CNS injury, because they mediate tissue damage and invasion of blood-derived immunocompetent cells. A factor recognized as a potential neurotoxic microglial secretion product is tissueplasminogen activator (t-PA); it aggravates neuronal injury after ischemia (44). One key mediators of cytotoxicity in the CNS secreted by microglia is NO (45), this molecule displays a wide array of biological activities, ranging from cytotoxicity to neuroprotective effects and neurotransmission (46). NO acts directly as neurotoxic via excitotoxic mechanisms (47). Little is known about cellular mechanisms regulating reactive oxygen species (ROS) production by activated microglia under 
pathological conditions, but, in microglia can produce ROS in different ways, e. g., NADPH oxidase, mitochondria or xanthine oxidase (48).

Phagocytic and cytotoxic functions of microglia are also triggered during CNS injury. Upon activation, microglia upregulate opsonic receptors including complement receptors (CR1, CR3, CR4) and Fc gamma receptors (I, II, III), which enhance phagocytic activity by binding to complement components and immunoglobulin fragments respectively (36).

\section{- Electrophysiological changes}

In the ion channels relays key functions of microglial physiology, for example, deramification of microglial cells in culture was inhibited by blockade of nonselective cation channels, this suggest that cation influx through such channels increases the intracellular osmolarity with a subsequent osmotic entry of water and cell swelling (49), and the ramification, or the adquisition of a amoeboid shape, is likely o be associated with stretch-activated Clchannels (50). Also has been observed that voltage- and/or $\mathrm{Ca} 2+$-activated $\mathrm{K}+$ channels regulate microglial proliferation (51), migration $(52,53)$, cytokine secretion $(54,55,56)$, production of free radicals $(57$, 58, 59). Strikingly, the intracellular conversion of pre-IL-1b to biologically active IL-1b is dependent for the decrease the cytoplasmic $\mathrm{K}+$ concentration (60) and blockade of delayed outward rectifier $\mathrm{K}+$ channels resulted in an inhibition of LPLstimulated microglial IL-1- release (61). Chloride channels have been found to be involved in microglial proliferation $(62,63)$, production of ROS $(64,65)$, iNOS expression and nitric oxide production (66), migration (52), phagocytosis (67) and ramification (68). During NADPH oxidase mediated respiratory burst of microglia are important the proton channels for charge compensation (69). Calcium has been evidenced to participate in transmission of brain-damage signals to microglia through long-range waves, this type of waves is induced by glutamate and is independent of ATP (70). What happens after activation is an even less known fact than the microglial activation. Microglial activation when no longer needed, finishes being an unremarkable phenomenon, and not even much noticed, but, may be some residual effects (71). When being challenged again, the experienced microglia could behave differently, and this could explain some chronically related problems like agerelated dysfunction or a neurodegenerative process $(72,17)$. However this behavior could be a protective effect, because the affected cells have been prepared by the former activation to respond quickly and efficiently in a second injury.

\section{Microglia: dual behavior?}

Exists the concept of secondary neuronal damage, i. e., microglia-mediated inflammation fell in secondary neuronal injury, and is in part built over the base that immunocompetent cells can aggravate neuronal demise, but whether microglial cells have a dual role, supportive or detrimental in neurotrauma and in others CNS acute or chronic pathologies has been the key question of almost a century. Has been stated that microglial behavior depends on several factors: the kind of stress and damage signals, the duration/timing of an impact, the microenvironment, the interaction with other cell types and, interestingly, even the age of an organism (73). There are a 
contrast between the potentially neurotoxic substances and the growth factors secreted by microglia, but it is impossible to predict the kind of microglia behavior (benefit or harm to surviving neurons) that will be induced by the lesion in an acute and chronic way. Macrophages and microglia can be classified into at least two subsets with distinct molecular phenotypes and effector functions depending on the activation pathway. The "activated" proinflammatory M1 macrophages, activated by LPS and by the proinflammatory cytokine IFN- $\gamma$, express CD86 and CD16/32 and produce high amounts of oxidative metabolites (NO and superoxide), proteases and proinflammatory cytokines. They play a central role in host defense against pathogens and tumor cells, and they can also damage healthy cells such as neurons and glial cells. In contrast, M2 macrophages are 'alternatively activated', anti-inflammatory macrophages induced by IL-4 and IL-13, and they express CD206 and arginase 1. The latter downregulate inflammation and promote tissue remodeling/repair and angiogenesis $(73,6)$. As previously mentioned, microglia can both produce and respond to cytokines, these can be either neuroprotective [e. g. IL-10, tumor growth factor (TGF)- $\beta$, TNF- $\alpha$ ] and/or neurotoxic (e. g. IL-1, TNF- $\alpha$, IFN- $\gamma$ ) (74). At high levels TNF- $\alpha$ is neurotoxic, but at low levels it can be neuroprotective (75). In models that simulate chronic systemic inflammation has been shown that microglia in young mice protect dopaminergic neurons against LPS, but in the old mice, microglia promote the death cell (76).

\section{Beneficial responses}

Almost all studies for evaluation of the role of microglia in pathological circumstances have been performed using in vitro cultured microglia, whereby there are limitations because those only shows one cell phenotype simulating a physiological or pathological condition, also, these models lacks of the microenvironmental interactions with other cells like neurons and astrocytes. Thanks to the phagocytic function, microglia can enter damaged brain regions and remove toxic detritus, invading pathogens and cell debris. In case of stimulation of TLR by pathogens is induced a proinflammatory reaction but, in cases of brain injury, the recognizing of phosphatidylserine of the cell membrane of damaged neurons induces an antiinflammatory reaction (74). Also in brain injury, microglial shows other beneficial activities like promoting protection to neurons (77), reestablishment of the neural environment (78), and has been evidenced that insufficient removal of myelin by microglia impairs the recruitment of oligodendrocyte precursor cells and induces an arrest of oligodendrocyte differentiation (78). Some cytokines secrete by microglia have an important role in protection, IL-6 can act on astrocytes and induce brain tissue repair (79), the IL-10 is an inhibitory cytokine of microglial apoptosis (80) and the TGF- $\beta$ also can be neuroprotective (81, $82,83)$ and it is elevated after injury (84, 85). These pleiotropic cytokines have central roles in vascular remodeling, immune suppression, immune homeostasis and repair after injury $(86,87,88,89)$. Furthermore, both TGF- $\beta$ and IL-10 inhibit macrophage and microglia activation by downregulating the expression of molecules associated with antigen presentation and production of proinflammatory cytokines, chemokines, and nitric and oxygen free radicals (90, 91, 
92). Microglia promote neuroplasticity and axonal regeneration, in addition to the monitoring and pruning of synapses (93, 94). Microglia can modify neural networks in multiple ways: promoting neuronal cell death, influencing neural circuitry by neuroplastic reorganization or synaptic stripping (95). Activated microglia also enhance angiogenesis $(96,97,98)$. Has been suggested that $\mathrm{T}$ cells, once activated (by encountering their relevant antigenpresenting cells), control the local innate response by activating resident microglia in a well-controlled way (99). They can also express neuroprotective proteins such as neurotrophins and glutamate transporters $(100,101)$. The latter transporters might help to reduce glutamate toxicity via uptake of glutamate.

\section{Detrimental responses}

Microglia have been implicated as a contributor to neuron damage, in models of excitotoxic cell death, phagocytic microglia contribute to neuronal degeneration and cell loss. Microglia can release glutamate, this neurotransmitter is well known to trigger excitotoxic neurodegeneration and cell death of astrocytes and oligodendrocytes $(102,103,104,105)$.

The exact mechanism leading to microglial overactivation is still not fully understood, but glial-neuronal crosstalk seems to be central (106), but because of activated microglia can release cytotoxic factors such as NO and ROS and secrete pro-inflammatory cytokines that can potentially damage neurons, oligodendrocytes or extracellular matrix structures directly or indirectly, i. e., activating astrocytes trough IL-1-mediated neurotoxicity $(107,34,108)$ have been considered as a "double-edged sword", and inhibition of its functions have been beneficial in some circumstances $(109,110$, 19, 111). Evidence is available to show the presence of activated microglia and their ability to induce cell death in the immature white matter, both in oligodendrocytes precursors and in astrocytes $(112,113)$.

The ROS (NO, hydrogen peroxide, superoxide) can kill invading microbes but also can induce neural damage and reactive gliosis (74). The intracellular ROS derived from NADPH oxidase play special roles in neurodegeneration for his dual functions (114, 115). The ROS released extracellularly can be directly toxic for neurons, especially dopaminergic ones, and when intracellular ROS concentrations raise, can alter the signaling cascade leading to microglia activation $(116,117,118,119)$. Microglia have been related to the progressive nature of neurodegenerative diseases through their capacity to be chronically activated by neuron death and fuelling, a self-renewing cycle of microglial activation followed by further neuron damage (reactive microgliosis). This selfpropelling cycle in microglial cells is possibly mediated by intracellular ROS and NO when they become activated by LPS (120). The activation of the prostaglandin E2 receptor of the prostaglandin E2 pathway can lead to microglia-induced paracrine neurotoxicity (121).

The acute microglia response is not considered detrimental, but when it became persistent, i.e., chronic microglial activation, is considered to be the most damaging response of microglia to injury through the previously stated mechanisms, that in the interaction damaged neuronhyperactivated microglia create a selfpropagating feedback loop that leads to an aberrant prolonged microglial activation and to neuronal death, chronic progression and neurodegeneration. 
Correspondence:

Dr. Luis Rafael Moscote-Salazar, University of Cartagena, Cartagena de Indias, Colombia. E-mail:mineurocirujano@aol.com

\section{References}

1. Harry GJ, Kraft AD. Microglia in the developing brain: A potential target with lifetime effects. NeuroToxicology. 2012; 33: p. 191-206.

2. Vilhardt. Microglia: phagocyte and glia cell. The International Journal of Biochemistry \& Cell Biology. 2005; 37: p. 17-21.

3. Greter M, Merad M. Regulation of microglia development and homeostasis. GLIA. 2013; 61: p. 121127.

4. Cajal SR. Contribución al conocimiento de la neuroglía del cerebro humano. Trab. Lab. Invest. Biol. Univ. Madrid. 1913; 18: p. 225-315.

5. del Rio Hortega P. Microglia. In Penfield W, editor. Citology \& cellular pathology of the nervous system. New York; 1932. p. 483-534.

6. Kigerl KA, Gensel C, Ankeny DP, Alexander JK, Donnelly DJ, Popovich PG. Identification of two distinct macrophage subsets with divergent effects causing either neurotoxicity or regeneration in the injured mouse spinal cord. The Journal of Neuroscience. 2009; 29(43): p. 13435-13444.

7. Luo XG, Chen SD. The changing phenotype of microglia from homeostasis to disease. Translational Neurodegeneration. 2012; 1(1): p. 1-13.

8. Saijo K, Crotti A, Glass CK. Regulation of microglia activation and deactivation by nuclear receptors. GLIA. 2013; 61: p. 104-111.

9. Shitaka Y, Tran HT, Bennett RE, Sanchez L, Levy MA, Dikranian K, et al. Repetitive closed-skull traumatic brain injury in mice causes persistent multifocal axonal injury and microglial reactivity. J Neuropathol Exp Neurol. 2011; 70(7): p. 551-567.

10. Jovanović Z. Mechanisms of neurodegeneration in Alzheimer's disease. Med Pregl. 2012; 65(7-8): p. 301-7.

11. Stertz L, Magalhães PV, Kapczinski F. Is bipolar disorder an inflammatory condition? The relevance of microglial activation. Curr Opin Psychiatry. 2013; 26(1): p. 19-26.

12. Shibata M. Mechanisms underlying migraine chronification. Rinsho Shinkeigaku. 2012; 52(11): p. 1012-3.

13. Derecki NC, Cronk JC, Kipnis J. The role of microglia in brain maintenance: implications for Rett syndrome. Trends Immunol. 2012.

14. Kettenmann $\mathrm{H}$, Hanisch UK, Noda $M$, Verkhratsky A. Physiology of Microglia. Physiol Rev.
2011; 91: p. 461-553.

15. Mannix RC, Whalen MJ. Traumatic Brain Injury,Microglia, and Beta Amyloid. Int J Alzheimers Dis. 2012;: p. 1-5.

16. Dheen ST, Kaur C, Ling EA. Microglial activation and its implications in the brain diseases. Curr Med Chem. 2007; 14: p. 1189-97.

17. Ladeby R, Wirenfeldt $M$, Garcia-Ovejero D, Fenger C, Dissing-Olesen L, Dalmau I, et al. Microglial cell population dynamics in the injured adult central nervous system. Brain Research Reviews. 2005; 48: p. 196- 206.

18. Engel S, Schluesener H, Mittelbronn M, Seid K, Adjodah D, Wehner HD, et al. Dynamics of microglial activation after human traumatic brain injury are revealed by delayed expression of macrophage-related proteins MRP8 and MRP14. Acta Neuropathol. 2000; 100: p. 313-322.

19. Hailer NP. Immunosuppression after traumatic or ischemic CNS damage: It is neuroprotective and illuminates the role of microglial cells. Progress in Neurobiology. 2008; 84: p. 211-233.

20. Galea I, Bechmann I, Perry H. What is immune privilege (not)? Trends Immunol. 2007; 28: p. 12-18.

21. Nimmerjahn A, Kirchhoff F, Helmchen F. Resting microglial cells are highly dynamic surveillants of brain parenchyma in vivo. Science. 2005; 308(5726): p. 1314-1318.

22. Minten C, Terry R, Deffrasnes C, Campbell IL, King N. IFN regulatory factor 8 is a key constitutive determinant of the morphological and molecular properties of microglia in the CNS. PLoS ONE. 2012; 7(11): p. e49851.

23. Jorgensen MB, Finsen BR, Jensen MB, Castellano B, Diemer NH, Zimmer J. Microglial and astroglial reactions to ischemic and kainic acid-induced lesions of the adult rat hippocampus. Exp. Neurol. 1993; 120.

24. Fujita T, Yoshimine T, Maruno M, Hayakawa T. Cellular dynamics of macrophages and microglial cells in reaction to stab wounds in rat cerebral cortex. Acta Neurochir. 1998; 140: p. 275-279.

25. Hailer NP, Grampp A, Nitsch R. Proliferation of microglia and astrocytes in the dentate gyrus following entorhinal cortex lesion: a quantitative bromodeoxyuridine-labelling study. Eur. J. Neurosci. 1999; 11: p. 3359-3364.

26. Yamamoto S, Nakajima K, Kohsaka S. Macrophage-colony stimulating factor as an inducer of microglial proliferation in axotomized rat facial nucleus. J Neurochem. 2010; 115(4): p. 1057-67.

27. Bianco F, Ceruti S, Colombo A, Fumagalli M, Ferrari D, Pizzirani C, et al. A role for P2X7 in microglial proliferation. J. Neurochem. 2006; 99: p. $745-758$.

28. Ringheim GE. Mitogenic effects of interleukin-5 
on microglia. Neuroscience Letters. 1995; 201: p. 131134.

29. Ganter S, Northoff H, Männel D, GebickeHärter PJ. Growth control of cultured microglia. J Neurosci Res. 1992; 33(2): p. 218-30.

30. Yang H, Feng GD, Liang Z, Vitale A, Jiao XY, Ju $\mathrm{G}$, et al. In vitro beneficial activation of microglial cells by mechanically-injured astrocytes enhances the synthesis and secretion of BDNF through p38MAPK. Neurochem Int. 2012; 61(2): p. 175-86.

31. Zhou LJ, Yang T, Wei X, Liu Y, Xin WJ, Chen Y, et al. Brain-derived neurotrophic factor contributes to spinal long-term potentiation and mechanical hypersensitivity by activation of spinal microglia in rat. Brain Behav Immun. 2011; 25(2): p. 322-34.

32. Zujovic V, Benavides J, Vigé X, Carter C, Taupin V. Fractalkine modulates TNF-alpha secretion and neurotoxicity induced by microglial activation. Glia. 2000; 29(4): p. 305-15.

33. Verge GM, Milligan ED, Maier SF, Watkins LR, Naeve GS, Foster AC. Fractalkine (CX3CL1) and fractalkine receptor (CX3CR1) distribution in spinal cord and dorsal root ganglia under basal and neuropathic pain conditions. Eur J Neurosci. 2004; 20(5): p. 1150-60.

34. Liu W, Tang Y, Feng J. Cross talk between activation of microglia and astrocytes in pathological conditions in the central nervous system. Life Sciences. 2011; 89(141-146).

35. Panatier A, Robitaille R. The soothing touch: microglial contact influences neuronal excitability. Dev Cell. 2012; 23(6): p. 1125-6.

36. Yang I, Han SJ, Kaur G, Crane C, Parsa AT. The role of microglia in central nervous system immunity and glioma immunology. J Clin Neurosci. 2010; 17(1): p. 6-10.

37. Parkhurst CN, Gan WB. Microglia dynamics and function in the CNS. Current Opinion in Neurobiology. 2010; 20: p. 595-600.

38. Noda M, Ifuku M, Mori Y, Verkhratsky A. Calcium Influx Through Reversed NCX Controls Migration of Microglia. Adv Exp Med Biol. 2013; 961: p. 289-94.

39. Haynes SE, Hollopeter G, Yang G, Kurpius D, Dailey ME, Gan WB, et al. The P2Y12 receptor regulates microglial activation by extracellular nucleotides. Nat Neurosci. 2006; 9: p. 1512-1519.

40. Wu LJ, Vadakkan KI, Zhuo M. ATP-induced chemotaxis of microglial processes requires $\mathrm{P} 2 \mathrm{Y}$ receptor-activated initiation of outward potassium currents. Glia. 2007; 55: p. 810-821.

41. Gibson RM, Rothwell NJ, Le Feuvre RA. CNS injury: the role of the cytokine IL- 1 . The Veterinary Journal. 2004; 168: p. 230-237.

42. Li W, Liu HD, You C, Zhou ML, Ling HP, Shen
W, et al. Enhanced cortical expression of myeloid differentiation primary response protein 88 (Myd88) in patients with traumatic brain injury. J Surg Res. 2012 Nov 22.

43. John GR, Lee SC, Song X, Rivieccio M, Brosnan CF. IL-1-regulated responses in astrocytes: relevance to injury and recovery. Glia. 2005; 49(2): p. 161-76.

44. Tsirka SE. Clinical implications of the involvement of tPA in neuronal cell death. J. Mol. Med. 1997; 75: p. 341-347.

45. Nakamichi K, Saiki M, Sawada M, Yamamuro Y, Morimoto K, Kurane I. Double-stranded RNA stimulates chemokine expression in microglia through vacuolar $\mathrm{pH}$-dependent activation of intracellular signaling pathways. J Neurochem. 2005; 95(1): p. 27383.

46. Zielasek J, Hartung HP. Molecular mechanismos of mircoglial activation. Advances in neuroimmunology. 1996; 6: p. 191-222.

47. Michikawa M, Lim KT, McLarnon JG, Kim SU. Oxygen radicalinduced neurotoxicity in spinal cord neuron cultures. J. Neurosci. Res. 1994; 37: p. 62-70.

48. Schilling T, Eder C. Stimulus-dependent requirement of ion channels for microglial NADPH oxidase-mediated production of reactive oxygen species. Journal of Neuroimmunology. 2010; 225: p. 190-194. 49. Schilling T, Lehmann F, Ruckert B, Eder C. Physiological mechanisms of lysophosphatidylcholineinduced de-ramification of murine microglia. J. Physiol. 2004; 557: p. 105-120.

50. Eder C, Klee R, Heinemann U. Involvement of stretch-activated Cl- channels in ramification of murine microglia. J. Neurosci. 1998; 18: p. 7127-7137.

51. Kotecha SA, Schlichter LC. A Kv1. 5 to Kv1. 3 switch in endogenous hippocampal microglia and a role in proliferation. J. Neurosci. 1999; 19: p. 10680-10693.

52. Rappert A, Biber K, Nolte C, Lipp M, Schubel A, $\mathrm{Lu} \mathrm{B}$, et al. Secondary lymphoid tissue chemokine (CCL21) activates CXCR3 to trigger a Cl- current and chemotaxis in murine microglia. J. Immunol. 2002; 168 : p. 3221-3226.

53. Schilling T, Stock C, Schwab A, Eder C. Functional importance of $\mathrm{Ca} 2+$-activated $\mathrm{K}+$ channels for lysophosphatidic acid-induced microglial migration. Eur. J. Neurosci. 2004; 19: p. 1469-1474.

54. Caggiano AO, Kraig RP. Prostaglandin E2 and 4aminopyridine prevent the lipopolysaccharide-induced outwardly rectifying potassium current and interleukin$1 \beta$ production in cultured rat microglia. J. Neurochem. 1998; 70: p. 2357-2368.

55. Franciosi S, Ryu JK, Choi HB, Radov L, Kim SU, McLarnon JG. Broad-spectrum effects of 4aminopyridine to modulate amyloid $\beta 1-42$-induced cell signaling and functional responses in human microglia. J. Neurosci. 2006; 26: p. 11652-11664. 
56. Stock C, Schilling T, Schwab A, Eder C. Lysophosphatidylcholine stimulates IL-1 $\beta$ release from microglia via a P2X7 receptor-independent mechanism. J. Immunol. 2006; 177: p. 8560-856.

57. Khanna R, Roy L, Zhu X, Schlichter LC. K+ channels and the microglial respiratory burs. Am. J. Physiol. 2001; 280: p. C796-C806.

58. Fordyce CB, Jagasia R, Zhu X, Schlichter LC. Microglia Kv1. 3 channels contribute to their ability to kill neurons. J. Neurosci. 2005; 25: p. 7139-7149.

59. Kaushal V, Koeberle PD, Wang Y, Schlichter LC. The Ca2+-activated $\mathrm{K}+$ channel KCNN4/KCa3. 1 contributes to microglia activation and nitric oxide dependent neurodegeneration. J. Neurosci. 2007; 27: p. 234-244.

60. Cheneval D, Ramage P, Kastelic T, Szelestenyi T, Niggli $\mathrm{H}$, Hemmig $\mathrm{R}$, et al. Increased mature interleukin-1beta (IL-1beta) secretion from THP-1 cells induced by nigericin is a result of activation of p45 IL1beta-converting enzyme processin. J. Biol. Chem. 1998; 273: p. 17846-17851.

61. Caggiano AO, Kraig RP. Prostaglandin E2 and 4aminopyridine prevent the lipopolysaccharide-induced outwardly rectifying potassium current and interleukin1beta production in cultured rat microglia. J. Neurochem. 1998; 70: p. 2357-2368.

62. Schlichter LC, Sakellaropoulos G, Ballyk B, Pennefather PS, Phipps DJ. Properties of $\mathrm{K}+$ and Clchannels and their involvement in proliferation of rat microglial cel. Glia. 1996; 17: p. 225-236.

63. Novarino G, Fabrizi C, Tonini R, Denti MA, Malchiodi-Albedi F, Lauro GM, et al. Involvement of the intracellular ion channel CLIC1 in microgliamediated $\beta$-amyloid-induced neurotoxicity. J. Neurosci. 2004; 24: p. 5322-5330.

64. Thomas MP, Chartrand K, Reynolds A, Vitvitsky V, Banerjee R, Gendelman HE. Ion channel blockade attenuates aggregated alpha synuclein induction of microglial reactive oxygen species: relevance for the pathogenesis of Parkinson's disease. J. Neurochem. 2007; 100: p. 503-519.

65. Milton RH, Abeti R, Averaimo S, DeBiasi S, Vitellaro L, Jiang L, et al. CLIC1 function is required for $\beta$-amyloid-induced generation of reactive oxygen species by microglia. J. Neurosci. 2008; 28: p. 1148811499.

66. Kjaer K, Strøbaek D, Christophersen P, Rønn LC. Chloride channel blockers inhibit iNOS expression and $\mathrm{NO}$ production in IFN $\gamma$-stimulated microglial BV2 cells. Brain Res. 2009; 1281: p. 15-24.

67. Ducharme G, Newell EW, Pinto C, Schlichter LC. Small-conductance Cl- channels contribute to volume regulation and phagocytosis in microglia. Eur. J. Neurosci. 2007; 26: p. 2119-2130.

68. Eder C. Ion channels in microglia (brain macrophages). Am. J. Physiol. 1998; 275: p. C327C342.

69. Thomas MP, Chartrand K, Reynolds A, Vitvitsky V, Banerjee R, Gendelman HE. Ion channel blockade attenuates aggregated alpha synuclein induction of microglial reactive oxygen species: relevance for the pathogenesis of Parkinson's disease. J. Neurochem. 2007; 100: p. 503-519.

70. Sieger D, Moritz C, Ziegenhals T, Prykhozhij S, Peri F. Long-range $\mathrm{Ca} 2+$ waves transmit brain-damage signals to microglia. Dev Cell. 2012; 22(6): p. 1138-48.

71. Hanisch UK, Kettenmann H. Microglia: active sensor and versatile effector cells in the normal and pathologic brain. Nat Neurosci. 2007; 10(11): p. 138794.

72. Block ML, Zecca L, Hong JS. Microglia-mediated neurotoxicity: uncovering the molecular mechanisms. Nat Rev Neurosci. 2007; 8: p. 57-69.

73. Czeh M, Gressens P, Kaindl AM. The Yin and Yang of Microglia. Dev Neurosci. 2011; 33: p. 199-209.

74. Walter L, Neumann H. Role of microglia in neuronal degeneration and regeneration. Semin Immunopathol. 2009; 31: p. 513-525.

75. Bruce AJ, Boling W, Kindy MS, Peschon J, Kraemer PJ, Carpenter MK, et al. Altered neuronal and microglial responses to excitotoxic and ischemic brain injury in mice lacking TNF receptors. Nat Med. 1996; 2(7): p. 788-94.

76. Sawada M, Sawada H, Nagatsu T. Effects of aging on neuroprotective and neurotoxic properties of microglia in neurodegenerative diseases. Neurodegener Dis. 2008; 5: p. 254-256.

77. Kiyama $\mathrm{H}$. The fate of injured motor neurons and the behavior of surrounding glial cells. Rinsho Shinkeigaku. 2012; 52(11): p. 934-6.

78. Kotter MR, Li WW, Zhao C, Franklin RJ. Myelin impairs CNS remyelination by inhibiting oligodendrocyte precursor cell differentiation. J Neurosci. 2006; 26: p. 328-322.

79. Streit WJ, Hurley SD, McGraw TS, SempleRowland SL. Comparative evaluation of cytokine profiles and reactive gliosis supports a critical role for interleukin-6 in neuron-glia signaling during regeneration. J Neurosci Res. 2000; 61: p. 10-20.

80. Strle K, Zhou JH, Broussard SR, Venters HD, Johnson RW, Freund GG, et al. IL-10 promotes survival of microglia without activating Akt. J Neuroimmunol. 2002; 122(1-2): p. 9-19.

81. Dolga AM, Culmsee C. Protective Roles for Potassium SK/K(Ca)2 Channels in Microglia and Neurons. Front Pharmacol. 2012; 3: p. 196.

82. Rodríguez-Martínez G, Velasco I. Activin and TGF- $\beta$ effects on brain development and neural stem cells. CNS Neurol Disord Drug Targets. 2012.

83. Dobolyi A, Vincze C, Pál G, Lovas G. The 
neuroprotective functions of transforming growth factor Beta proteins. Int J Mol Sci. 2012; 13(7): p. 821958.

84. McTigue DM, Popovich PG, Morgan TE, Stokes BT. Localization of transforming growth factor-beta1 and receptor mRNA after experimental spinal cord injury. Exp Neurol. 2000; 163: p. 220-230.

85. Doyle KP, Cekanaviciute E, Mamer LE, Buckwalter MS. TGF $\beta$ signaling in the brain increases with aging and signals to astrocytes and innate immune cells in the weeks after stroke. J Neuroinflamm. 2010; 7: p. 62.

86. Dhandapani KM, Brann DW. Transforming growth factor-beta: a neuroprotective factor in cerebral ischemia. Cell Biochem Biophys. 2003; 39: p. 13-22.

87. Pepper MS. Transforming growth factor-beta: vasculogenesis, angiogenesis, and vessel wall integrity. Cytokine Growth Factor Rev. 1997; 8: p. 21-43.

88. Bertolino P, Deckers M, Lebrin F, ten Dijke P. Transforming growth factor-beta signal transduction in angiogenesis and vascular disorders. Chest. 2005; 128: p. 585S-590.

89. Li MO, Wan YY, Sanjabi S, Robertson AK, Flavell RA. Transforming growth factor-beta regulation of immune responses. Annu Rev Immunol. 2006; 24: p. 99-146.

90. Aloisi F, De Simone R, Columba-Cabezas S, Levi G. Opposite effects of interferon- $\gamma$ and prostaglandin E2 on tumor necrosis factor and interleukin-10 production in microglia: a regulatory loop controlling microglia pro- and anti-inflammatory activities. J Neurosci Res. 1999; 56: p. 571-580.

91. O'Keefe GM, Nguyen VT, Benveniste EN. Class II transactivator and class II MHC gene expression in microglia: modulation by the cytokines TGF- $\beta$, IL-4, IL-13 and IL-10. Eur J Immunol. 1999; 29: p. 12751285.

92. Frei K, Lins H, Schwerdel C, Fontana A. Antigen presentation in the central nervous system. The inhibitory effect of IL-10 on MHC class II expression and production of cytokines depends on the inducing signals and the type of cell analyzed. J Immunol. 1994; 152: p. $2720-2728$.

93. Gordon S. Alternative activation of macrophages. Nat Rev Immunol. 2003; 3: p. 23-35.

94. Chen MK, Guilarte TR. Translocator protein 18 $\mathrm{kDa}$ (TSPO): molecular sensor of brain injury and repair. Pharmacol Ther. 2008; 118: p. 1-17.

95. Perry VH, Nicoll JA, Holmes C. Microglia in neurodegenerative disease. Nat Rev Neurol. 2010; 6: p. 193-201.

96. Ling L, Zeng J, Pei Z, Cheung RT, Hou Q, Xing $\mathrm{S}$, et al. Neurogenesis and angiogenesis within the ipsilateral thalamus with secondary damage after focal cortical infarction in hypertensive rats. Cereb Blood
Flow Metab. 2009; 29: p. 1538-1546.

97. Jantaratnotai N, Schwab C, Ryu JK, McGeer PL, McLarnon JG. Converging perturbed microvasculature and microglial clusters characterize Alzheimer disease brain. Curr Alzheimer Res. 2010; 7: p. 625-636.

98. Welser JV, Li L, Milner R. Microglial activation state exerts a biphasic influence on brain endothelial cell proliferation by regulating the balance of TNF and TGF- 31. J Neuroinflamm. 2010; 7: p. 89.

99. Shaked I, Porat Z, Gersner R, Kipnis J, Schwartz M. Early activation of microglia as antigen-presenting cells correlates with $\mathrm{T}$ cell-mediated protection and repair of the injured central nervous system. Journal of Neuroimmunology. 2004; 146: p. 84-93.

100. Nakajima K, Honda S, Tohyama Y, Imai $Y$, Kohsaka S, Kurihara T. Neurotrophin secretion from cultured microglia. J. Neurosci. Res. 2001; 65: p. 322331.

101. Nakajima K, Tohyama Y, Kohsaka S, Kurihara T. Ability of rat microglia to uptake extracellular glutamate. Neurosci. Lett. 2001; 307: p. 171- 174.

102. Chang ML, Wu CH, Chien HF, Jiang-Shieh YF, Wen CY. Microglia/macrophages responses to kainateinduced injury in the rat retina. Neurosci. Res. 2006; 54(3): p. 202-212.

103. Cho IH, Hong J, Suh EC, Kim JH, Lee JE, Lee S, et al. Roles of microglial IKKbeta in kainic acid-induced hippocampal neuronal cell death. Brain. 2008; 131(11): p. 3019-3033.

104. Jim JE, Kwak SE, Jo SM, Kang TC. Blockade of $\mathrm{P} 2 \mathrm{X}$ receptor prevents astroglial death in the dentate gyrus following pilocarpine-induced status epilepticus. Neurol. 2009; 31(9): p. 982-8.

105. Yenari MA, Kauppinen TM, Swanson RA. Microglial activation in stroke: therapeutic targets. Neurotherapeutics. 2010; 7: p. 78-391.

106. Liu W, Tang Y, Feng J. Cross talk between activation of microglia and astrocytes in pathological conditions in the central nervous system. Life Sciences. 20011; 89(141-146).

107. Chao CC, Hu S, Sheng WS, Bu D, Bukrinsky MI, Peterson PK. Cytokine-stimulated astrocytes damage human neurons via a nitric oxide mechanism. Glia. 1996; 16(3): p. 276-84.

108. Retamal MA, Froger N, Palacios-Prado N, Ezan P, Sáez PJ, Sáez JC, et al. Cx43 hemichannels and gap junction channels in astrocytes are regulated oppositely by proinflammatory cytokines released from activated microglia. J Neurosci. 2007; 27(50): p. 13781-92.

109. Microglial activation induced by brain trauma is suppressed by post-injury treatment with a PARP inhibitor. Journal of Neuroinflammation. 2012; 9: p. 31. 110. Kumar A, Loane DJ. Neuroinflammation after traumatic brain injury: Opportunities for therapeutic intervention. Brain, Behavior, and Immunity. 2012; 26: 
p. 1191-1201.

111. Surace MJ, Block ML. Targeting microgliamediated neurotoxicity: the potential of NOX2 inhibitors. Cell Mol Life Sci. 2012; 69(14): p. 2409-27.

112. Tahraouis SL, Marret S, Bodénant C, Leroux P, Dommergues MA, Evrard P, et al. Central role of microglia in neonatal excitotoxic lesions of the murine periventricular white matter. Brain Pathol. 2001; 11(1): p. 56-71.

113. Dommergues MA, Plaisant F, Verney C, Gressens P. Early microglial activation following neonatal excitotoxic brain damage in mice: a potential target for neuroprotection. Neuroscience. 2003; 121: p. 619-628.

114. Choi SH, Aid S, Kim HW, Jackson SH, Bosetti F. Inhibition of NADPH oxidase promotes alternative and anti-inflammatory microglial activation during neuroinflammation. J. Neurochem. 2012; 120: p. 292301.

115. Groemping Y, Rittinger K. Activation and assembly of the NADPH oxidase: a structural. Biochem J. 2005; 386: p. 401-416.

116. Sedeek M, Hébert RL, Kennedy CR, Burns KD, Touyz RM. Molecular mechanisms of hypertension: role of Nox family NADPH oxidases. Curr. Opin. Nephrol. Hypertens. 2009; 18: p. 122-127.

117. Muller G, Morawietz H. Nitric oxide, NAD(P)H oxidase, and atherosclerosis. Antioxid. Redox Signal. 2009; 11: p. 1711-1731.

118. Robinson JM. Phagocytic leukocytes and reactive oxygen species. Histochem. Cell Biol. 2009; 131: p.
465-469.

119. Huh SH, Chung YC, Piao Y, Jin MY, Son HJ, Yoon NS, et al. Ethyl pyruvate rescues nigrostriatal dopaminergic neurons by regulating glia activation in a mouse model of Parkinson's disease. J. Immunol. 2011; 187: p. 960-969.

120. Lijia Z, Siqi Z, Xiaoxiao W, Chunfu W, Jingyu Y. A self-propelling cycle mediated by reactive oxide species and nitric oxide exists in LPS-activated microglia. Neurochemistry International. 2012; 61: p. 1220-1230.

121. Kim YT, Moon SK, Maruyama T, Narumiya S, Doré S. Prostaglandin FP receptor inhibitor reduces ischemic brain damage and neurotoxicity. Neurobiol Dis. 2012; 48(1): p. 58-65.

122. Etemad S, Zamin M, Ruitenberg MJ, Filgueira L. A novel in vitro human microglia model: Characterization of human monocyte-derived microglia. Journal of Neuroscience Methods. 2012; 209: p. 79-89.

123. Ellis SL, Gysbers V, Manders PM, Li W, Hofer MJ, Müller $M$, et al. The cell-specific induction of CXC chemokine ligand 9 mediated by IFN-gamma in microglia of the central nervous system is determined by the myeloid transcription factor PU. 1. J Immuno. 2010; 185(3): p. 1864-77.

124. Bsibsi M, Ravid R, Gveric D, van Noort JM. Broad expression of Toll-like receptors in the human central nervous system. J Neuropathol Exp Neurol. 2002; 61(11): p. 1013-21. 